\title{
Approaches of Applying Non-Darcian Flow Equations to Predicting Groundwater Rebound in Response to Coal Mine Closure
}

\author{
Shuning Dong ${ }^{1}$, Hao Wang ${ }^{1}$, Wanfang Zhou ${ }^{2 *}$ \\ ${ }^{1} X i$ 'an Research Institute of China Coal Technology \& Engineering Group, Xi'an, Shaanxi 710054, China \\ ${ }^{2}$ ZeoEnvironmental, Knoxville, Tennessee, United States
}

*Corresponding Author: Wanfang Zhou, ZeoEnvironmental, Knoxville, Tennessee, United States

\begin{abstract}
Groundwater rebound occurs after closure of coal mines that are below groundwater levels and cessation of dewatering. While a number of modeling approaches have been developed in recent years to predict such rebounds and facilitate post-closure proactive management, the lack of detailed input data and complex mine void structures make these modeling approaches less effective. Traditional Darcian-flow based groundwater flow models do not provide the correct simulation of multi-porosity flow with preferential flow along mine voids including mined-out areas, roadways, and shafts. Models that account for the non-Darcian flow in mine voids include black-box model, pipe-network model, and pipe-pond models. Depending on volume of mine voids and their connections, these models can predict the general trends in groundwater rebound and water quality. They can help determine the general timeframes to approach the full recovery. In particular, the black-box approach, which does not require detailed geometric and hydraulic data of mine voids, takes advantage of the routine mining records on mining extent and dewatering activity. Examples are presented to show that the predictions can provide useful information for more sophisticated modeling of groundwater flow dynamics after mine closure. The hydrogeological insights into the mine void system that are gained from such exercises are also helpful in future re-use of flooded voids as underground reservoirs or resources for low-carbon heating systems.
\end{abstract}

Keywords: Coal mine closure, Groundwater rebound, Black-box model, Pipe-network model, Pipe-pond model

\section{INTRODUCTION}

Figure 1 shows the number of coal mines in China over the past 20 years from 1998 to 2018. The number of coal mines decreased from 80,000 in 1998 to 5,800 in 2018, a reduction of approximately $92 \%$. Closure of the mines resulted from exhaustion of coal resources in old mining districts and integrated resources management by strategically abandoning smaller coal mines. The trend of coal mine closure is anticipated to continue in China in the near future.

Such massive mine closure is not limited to China but has also been experienced in many other countries including the Unites States, United Kingdom, and South Africa (Aljoe 1994; Younger 2000; Younger et al. 2006; Wolkersdorfer 2006; Li et al. 2014). Where mining of coal extends below the groundwater table or under potentiometric pressure, sustained dewatering is necessary throughout the life of the mine to prevent flooding of active parts of the workings (Younger \& Thorn 2006). As a consequence, the natural hydro geological conditions are disrupted, and the local and regional hydro geological regime is controlled to a large extent by the dewatering. In many coal mines or coalfields with multiple mines, the scale of hydro geological disruption can be many hundreds or thousands of square kilometers. Coal mine closure usually comes with discontinuation of mine dewatering, which results in an increase in the groundwater level. The groundwater level rise floods the underground voids generated due to mining activities or flowing back into the formations surrounding the mine. This flooding process is often referred to as groundwater rebound. Predicting the groundwater rebound in response to mine closure is important because the rebound leads to the following hydro geological consequences pertinent to environmental impacts, resource conservation, and hazard risk management. 
- The most direct consequence of groundwater rebound is water pooling, which is controlled by the extent of cone of depression caused by dewatering, void volume of old workings, hydraulic connectivity between old workings, extent of induced fractures in the overlying formation, inflow rate, and outflow rates. Based on site-specific hydrogeologic conditions and mining history, water pooling can be unconfined or confined, in one location or multiple locations, or have one groundwater level or multiple groundwater levels. Water pooling can encompass hundreds of kilometers (U. S. Office of Surface Mining 2014) and may pose a safety threat to neighboring active mines if they are inadvertently intercepted. The water inrush incident that occurred at Quecreek Coal Mine, Pennsylvania (PA) in 2002 was caused by breakout of a neighboring water pool (PA Department of Environmental Protection, 2003). Nine miners were trapped for four days and ultimately rescued. The outcome, however, of the water inrush that occurred in China in 2005 and also resulted from water pooling in an abandoned mined out void was much worse. The incident caused 121 fatalities and economic loss of more than 47 million Yuan (Cui et al. 2018).

- Change in groundwater quality is another important consequence of groundwater rebound. Flooding results in rapid dissolution of the deposited salts by oxidation of pyrite and other minerals (Wood et al. 1999; Stoertz et al. 2001; Zhou et al. 2006; Hu et al. 2010; Liu et al. 2011). Based on a recent survey in the closed mines of China (Wu et al. 2017), there are four types of mine water, i.e., acid mine water, high salinity mine water, high sulfate mine water, and high fluorine mine water. Water pools containing contaminants in closed mines can be underground pollution sources to natural water resources and the environment. Post-closure water quality may experience the "first-flush" phenomenon in many mines (Gzyl \& Banks 2007). Water quality deteriorated immediately after the closure but improved over a long period of time due to dilution by fresh recharge and depletion of pyrite. Water quality stratification has been observed in some mine pools where only the upper portion is being actively flushed, and the lower part contains stagnant poor quality mine water (Wolkersdorfer 2006; Ladwig et al. 1984).

- The third consequence of groundwater rebound is related to ground subsidence and collapse (Pan et al. 2018). Sudden flooding of shallow workings can cause weakening of mine supports, which may lead to subsidence. Three mechanisms contribute to the ground subsidence: (1) slaking and pillar failure in old workings in response to wetting; (2) direct erosion of mine voids by rapidly flowing mine water or pressurized gases; and (3) reactivation of previously dormant faults that were intercepted by old mine workings subject to recent flooding. The ground subsidence leads to either small-scale collapses or large-scale enclosed basins, which enhance the recharge conditions.

- In some coal mines, changes in hydrogeology affect occurrence and migration of mine gases (Jardine et al. 2009). Mine gases can cause concerns of explosion and vapor intrusion. Predictions of post-closure responses are important from a public safety perspective.

- Groundwater rebound also provides opportunities for beneficial use of mine-induced voids. Flooded mine workings may be used as underground water reservoirs where water quality permits (Dinger et al. 2006; Hobba 1987; Ordoñez et al. 2012). Mine water is an ideal source upon which to base heat pump solutions for space-heating and cooling of housing complexes, large commercial developments or public buildings (Younger 2014; Zeng et al. 2017).

A number of modeling approaches have been developed in recent decades to predict groundwater rebound in response to mine closure (Kortas and Younger 2007; Zhou et al. 2011; Light and Donovan 2015, Adams and Younger 2001; Boyaud and Therrien 2004; Winters and Capo 2004; McCoy et al. 2006; Feng 2006; Hamm et al. 2008). Mine groundwater rebound prediction technology provides quantitative information to address the above-mentioned consequences associated with abandoned mines. The traditional Darcian-flow based models such as MODFLOW (United States Geological Survey) have been reported for rebounding simulations (Toran and Bradbury 1988; Sherwood \& Younger 1997; Huisamen \& Wolkersdorfer 2016). The rationale for MODFLOW application to predicting groundwater rebound is that the model domains behave as equivalent porous media at the scale of study.

\section{Conceptual Site Model of Groundwater Rebound after Mine Closure}

Groundwater environment in mines, however, is physically and hydraulically different from a "typical" aquifer. Analysis of the mine groundwater rebound phenomenon using a Darcian flow-based 
groundwater flow model presents many challenges (Adams \& Younger 2001; Pan et al. 2017; Wu et al. 2017). Major dominant flow-path features can be so extensive that they cannot be conveniently ignored even at large scales. Groundwater rebounds actually occur in multi-porosity media with void sizes varying over several orders of magnitude. Although the flow of groundwater in the strata surrounding a mine void can be assumed to be a laminar groundwater flow, flow in the mined voids including shafts, drifts and underground roadways is turbulent. In most cases, mine workings represent preferential flow pathways with variable and difficult-to-estimate hydraulic properties. The only geologic medium that may be analogous to abandoned mines is the karst system that consists of caves and conduits.

To overcome the limitations of the Darcian flow-based models, three types of model are developed that explicitly account for non-Darcian flow in the mined out voids: black-box model, pipe-network model, and pond-and-pipe model. Selection of the most appropriate model and the accuracy of the model prediction depend on development of a representative conceptual site model (CSM). Technical requirements on development of CSMs for abandoned mines can be found in the U. S. Environmental Protection Agency (USEPA) document "Best Practices for Preventing Sudden, Uncontrolled Fluid Mining Waste Releases" (USEPA, 2017). Inclusion of mining related structures makes it essential that any CSM is site-specific. Table 1 summarizes the major elements of a CSM for groundwater rebound. Availability of required elements will dictate the type of modeling and accuracy of results.

This paper focuses on applying non-Darcian flow equations to predict groundwater rebound in response to mine closure. The CSM should include recharge sources, mine workings, and pathways from recharge to mine working. The recharge data is often readily available for mines that have operated for years. The more critical element is the three-dimensional extent and sizes of mine workings. Any historical exploration reports, mine development plans, operation of mine workings should be reviewed for an initial assessment. Reports on blockages, collapse, instability, interconnections with other mines, and monitoring data on surface water, groundwater, and ground subsidence should be factored into the CSM. The SCM can also be improved with data collected through application of specialized techniques including geophysics, tracer test, laser or sonar scanning, and downhole videoing (USEPA, 2017; Love et al. 2005; Wolkersdorfer \& Hasche 2003). Because each mine site is unique in the hydro geological conditions and mine operations, a CSM is site-specific. The modeling exercises presented in this paper are not for a specific mine site. Instead they demonstrate three modeling tools that can be used to predict the groundwater rebound process. These models can be adapted to any mine site, provided that a CSM can be developed for it.

Table1. Major elements of CSM for abandoned mines

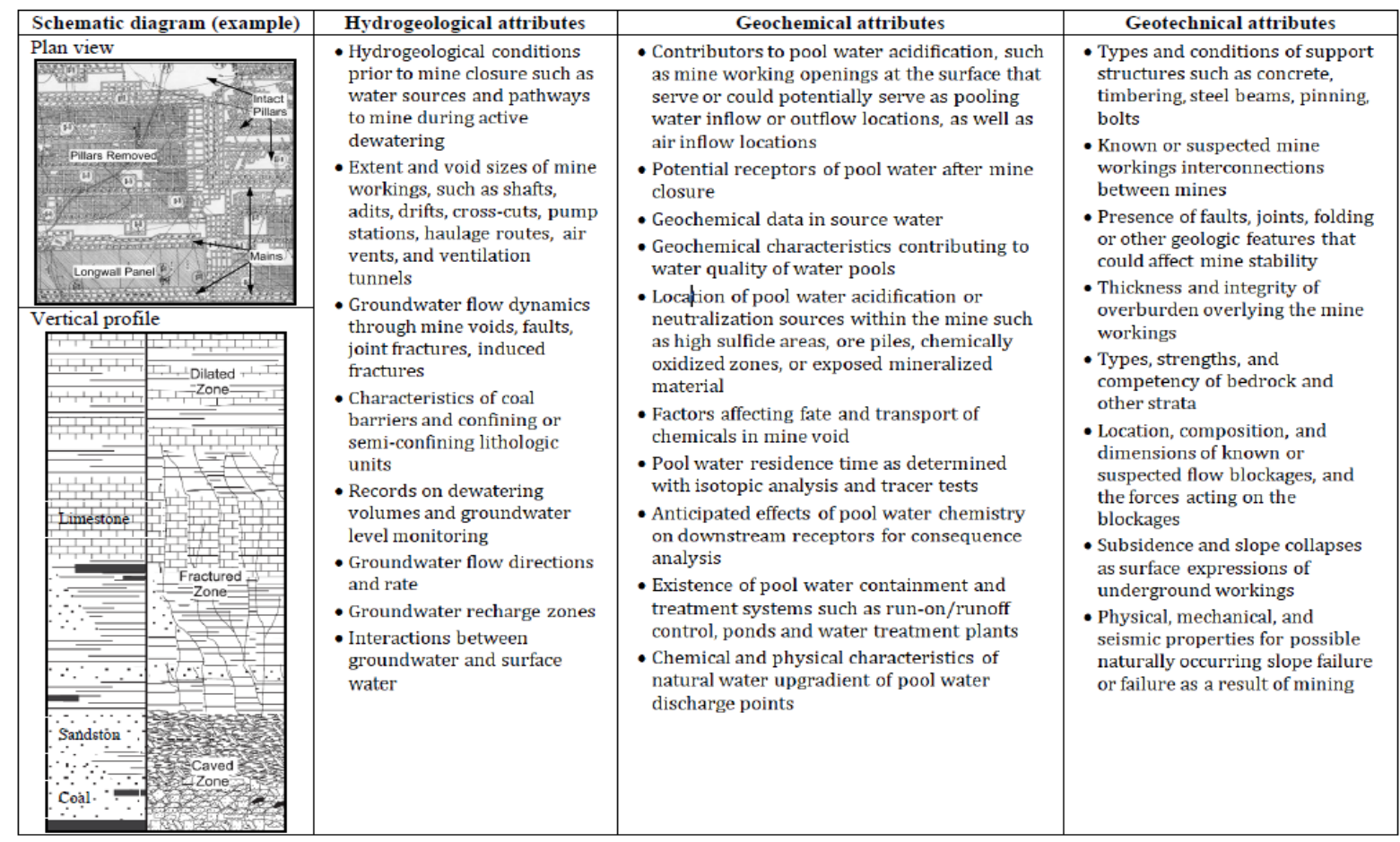




\subsection{Black-Box Model}

A black-box model is applicable to assessing post-closure hydrogeology of a coal mine where time, financial resources, and available data are limited. The best example of such a model is the water balance or water budget analysis. Therefore, this approach is suitable to a watershed or drainage-basin scale. The method does not require knowledge of mined void structures and detailed spatial hydro geological data at the mine. It relies on mining records on coal production and dewatering activities. The records of coal production help calculate volume of the mined voids. Conversion of coal production records to void space is relatively straightforward as long as the coal density and coal porosity are known. Such rudimentary calculations do not take into account the mine-induced voids/fractures, deformation of overlying strata, and any back-filling activities. Records of the pump rate/volume during dewatering provide valuable information on hydro geological conditions at the mine and surrounding areas. To account for these factors, the total mined void volume is adjusted by storage coefficient $\mathrm{S}$ (dimensionless), which is the effective ratio between the mined void volume available for flooding and the total calculated mined void.

Assume a regular-shaped mined void with surface area $\mathrm{A}\left(\mathrm{m}^{2}\right)$ and height $\mathrm{H}(\mathrm{m})$. For the addition of a given volume $\mathrm{V}_{\mathrm{w}}\left(\mathrm{m}^{3}\right)$ of water, the water level rise $\Delta h_{\mathrm{w}}$ can be expressed by:

$\Delta h_{w}=\frac{V_{w}}{A S}$

If the mine void can be assumed as an open reservoir, $S$ equals to 1 . In many abandoned mines, the mine voids consist of un-mined materials. The value of $S$ ranges from 0.01 to 0.5 with an average of 0.3 for closed mines in the United Kingdom (Younger 2016). Based on authors' experience in China, the value of $\mathrm{S}$ depends on type of rock in the overlying formations and mining method associated with coal recovery rate. The $\mathrm{S}$ value ranges from 0.4 to 0.8 in formations characterized with brittle deformation, 0.2 to 0.5 in formations characterized with ductile deformation, and 0.3 to 0.6 in formations consisting of both brittle and ductile deformations. A smaller $\mathrm{S}$ means a quicker rebound process.

Parameter $\mathrm{V}_{\mathrm{w}}$ is a function of rate of water inflow to the mined system and the selected time interval. Under the circumstances where no data is available to support sophisticated calculation of the water inflow rate, the records of pumped discharges can be used to estimate the potential inflow rate. As required by regulatory agencies, most coal mines have historical records of dewatering. The records help establish the relationship between pumping rate and mining level, or relationship between pumping rate and groundwater level drawdown or elevation. The relationship between measured pumping rate and groundwater level elevation gives the pumping rate at a specific groundwater elevation. The pumping rate can be reasonably assumed to be the inflow rate because the mine would be flooded at that specific elevation if the pumping rate were not equal to or greater than the inflow rate. Such a beneficial use of the pumping rate records does not consider the difference in meteorological conditions and changes in hydro geological conditions due to mining. However, such established relationships between inflow rate and groundwater head conform to the basic principle in hydrogeology, i.e., water flow rate is head-dependent.

Table 2 presents hypothetical records on mining activities to illustrate how the black-box can be used to calculate the rebound processes. The abandoned mine has extracted coals at four levels for different coal seams. Figure 1 shows the rebound process over time and the pumping rates at different mining levels. The rebound is analogous to an inverse process of dewatering for the flow rate. When the rebound reaches different elevations the inflow rate is adjusted to the pumping rates at those elevations. Figure 2 shows a stepped profile of water level recovery. The stepped groundwater level recovery is a common characteristic of groundwater rebounds in abandoned coal mines. For a total void volume of $1.2 \mathrm{M} \mathrm{m}^{3}$, it will take more than 16 years to complete the rebound. 


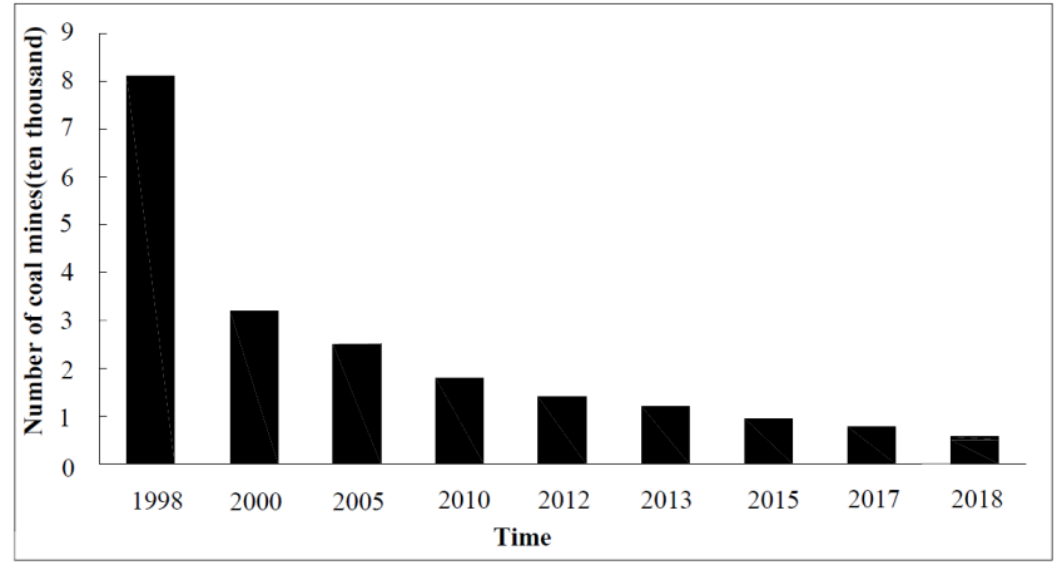

Figure1. Number of active coal mines in China

Table2. Records on mining activities for a hypothetical mine

\begin{tabular}{|c|c|c|c|c|c|}
\hline \multicolumn{7}{|c|}{ Mining Records } \\
\hline Mining Level & Elevation (m) & $\begin{array}{c}\text { Volume of } \\
\text { mine void } \\
\left(\mathbf{M ~ m}^{\mathbf{3}}\right)\end{array}$ & $\begin{array}{c}\text { Surface area } \\
\text { of mine void } \\
\left(\mathbf{m}^{\mathbf{2}}\right)\end{array}$ & $\begin{array}{c}\text { Height of } \\
\text { mine } \\
\text { void (m) }\end{array}$ & $\begin{array}{c}\text { Average pumping } \\
\text { rate during } \\
\text { dewatering (L/s) }\end{array}$ \\
\hline Mining Level I & 100 & 0.3 & 30,000 & 10 & 1.3 \\
\hline Mining Level II & 50 & 0.3 & 20,000 & 15 & 6.30 \\
\hline Mining Level III & 30 & 0.3 & 60,000 & 5 & 19.0 \\
\hline Mining Level IV & 0 & 0.3 & 30,000 & 10 & 31.55 \\
\hline
\end{tabular}

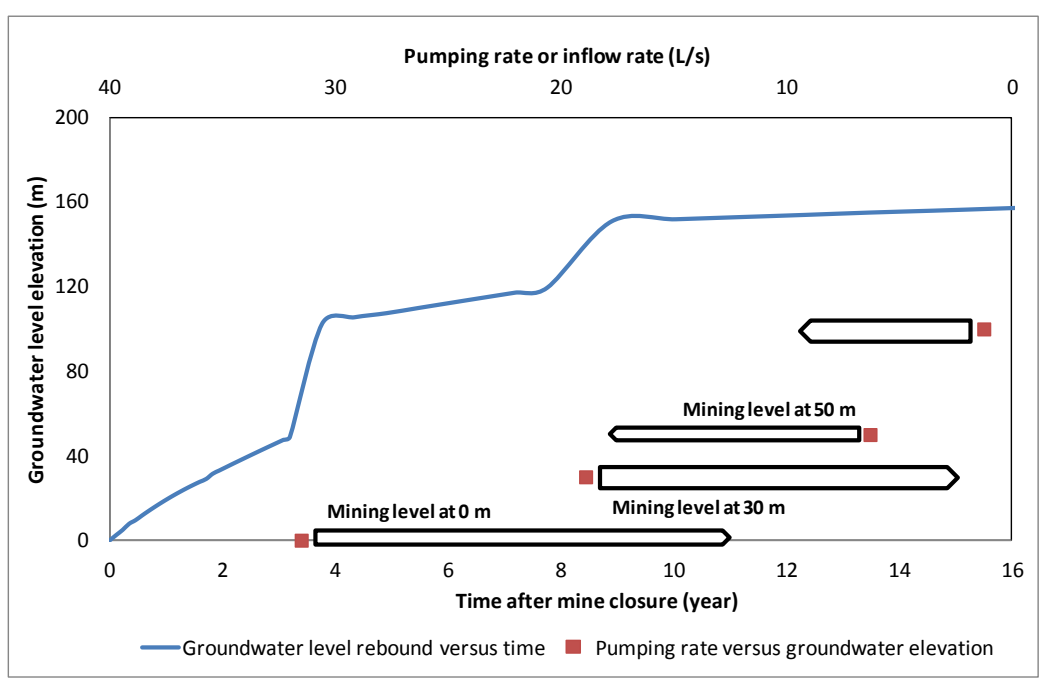

Figure2. Groundwater rebound prediction for a hypothetical mine closure using black-box model

\subsection{Pipe-network model}

A pipe network model is a physically based model that is constructed with knowledge of the void structures. A pipe network is adopted to allow the larger flow pathways to be discretized by a series of interconnected conduits (pipes). The network can be coupled with an equivalent porous-medium model to represent the interconnections between the regional aquifer and these conduits in the mined out strata. Examples of such models are MODFLOW-CFP (Conduit Flow Process) (Shoemaker et al. 2008) and 3D VSS-NET (Adams \& Younger 1997). The CFP was developed for simulating both laminar and turbulent groundwater flow in karst conduits or caves and is coupled with the popular MODFLOW program. The hydraulic model NET was developed specifically for simulating turbulent groundwater flow in mined out voids of abandoned mines and is coupled with VSS, which is a modeling program for variably-saturated porous medium domains (Adams 2014). The mathematical algorithm to solve the pipe network, to calculate pressure head and flow rates, varies slightly for 
different programs. However, the basic principles remain similar, using one of the following: DarcyWeisbach flow formula, Chezy-Manning formula, and exponential Hazen-Williams formula (Adams \& Younger 1997; Shoemaker et al.; 2008; Hamm et al. 2008). Each formula uses the following equation to calculate the head loss through a pipe between two nodes (Rossman 2000).

$\Delta_{L}=A q^{B}$

where $h_{L}$ is the head loss; $q$ is the flow rate; $A$ is referred to as the resistance coefficient; and $B$ is the flow exponent. Table 3 lists expressions for the resistance coefficient and values for the flow exponent for each of the formulas. Theoretically, the Darcy-Weisbach formula is the most correct and applies over all flow regimes and to all liquids. The Hazen-Williams formula is the most commonly used and can be used for turbulent flow in water only. The Chezy-Manning formula is more commonly used for open channel flow.

Table3. Parameter expressions in Equation (2) (Rossman 2000)

\begin{tabular}{|c|c|c|}
\hline Equation name & Resistance coefficient, A & Flow exponent, B \\
\hline Hazen-Williams & $4.727 \mathrm{C}^{-1.852} \mathrm{~d}^{-4.871} \mathrm{~L}$ & 1.852 \\
\hline Darcy-Weisbach & $0.0252 \mathrm{f}(\mathrm{e}, \mathrm{d}, \mathrm{q}) \mathrm{d}^{-5} \mathrm{~L}$ & 2 \\
\hline Chezy-Manning & $4.66 \mathrm{n}^{2} \mathrm{~d}^{-5.33} \mathrm{~L}$ & 2 \\
\hline $\begin{array}{l}\mathrm{C}=\text { Hazen-Williams roug } \\
\mathrm{e}=\text { Darcy-Weisbach roug } \\
\mathrm{f}=\text { friction factor }(\text { depend } \\
\mathrm{n}=\text { Manning roughness } \mathrm{c} \\
\mathrm{d}=\text { pipe diameter }(\mathrm{ft}) \\
\mathrm{L}=\text { pipe length }(\mathrm{ft}) \\
\mathrm{q}=\text { flow rate }(\mathrm{cfs})\end{array}$ & $\begin{array}{l}\text { ient } \\
\text { lent (ft) } \\
\text { a) }\end{array}$ & \\
\hline
\end{tabular}

Application of the pipe network model is illustrated for an abandoned mine, as shown schematically in Figure 3. The network is relatively simple and consists of six nodes and five pipes. The parameters of the nodes and pipes are presented in Table 4. Figure 4 shows the predicted groundwater level rebound, together with the predicted inflow rate to the mine void.

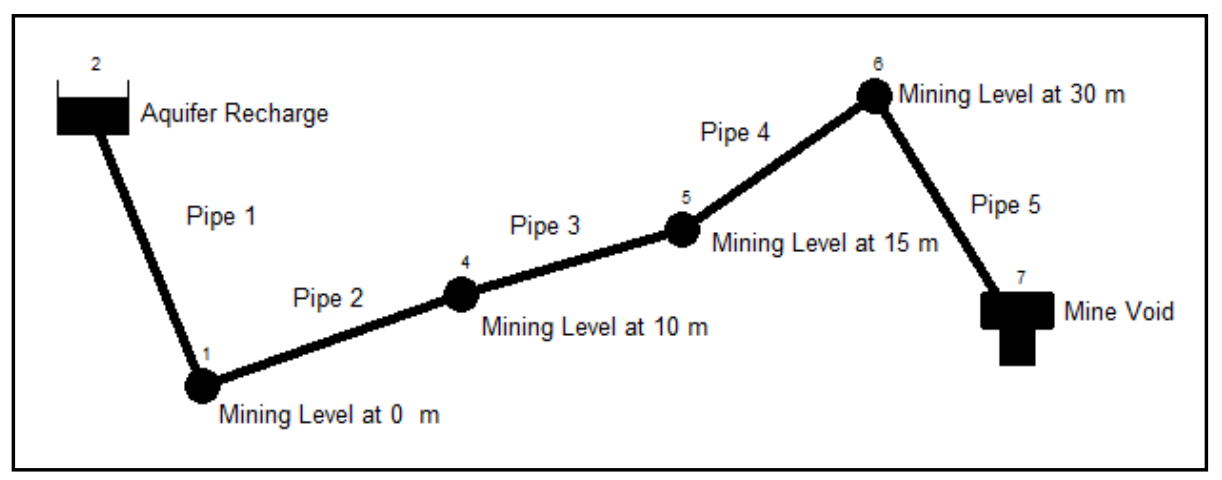

Figure3. Example pipe network for groundwater rebound simulation

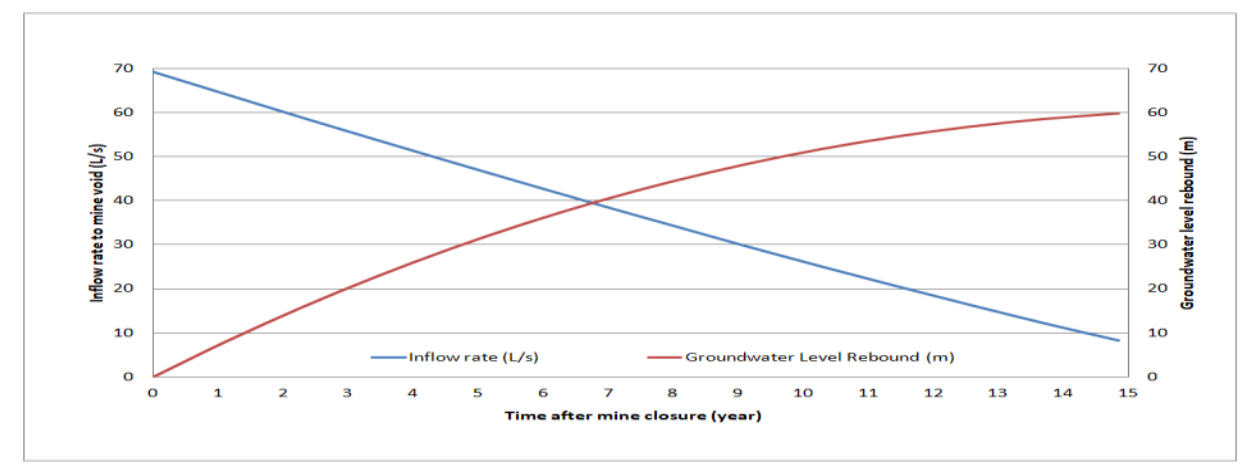

Figure4. Groundwater rebound prediction for pipe network in Figure 3 using pipe-network model 
Approaches of Applying Non-Darcian Flow Equations to Predicting Groundwater Rebound in Response to Coal Mine Closure

Table4. Parameters for the pipe network shown in Figure 3

\begin{tabular}{|c|c|c|c|c|c|c|c|c|}
\hline \multicolumn{3}{|c|}{ Node } & \multicolumn{3}{|c|}{ Pipe } & \multicolumn{3}{|c|}{ Mine Void } \\
\hline $\begin{array}{c}\text { Node } \\
\text { Number }\end{array}$ & Feature & $\begin{array}{l}\text { Elevation } \\
\quad(\mathrm{m})\end{array}$ & $\begin{array}{c}\text { Pipe } \\
\text { Number }\end{array}$ & $\begin{array}{c}\text { Diamet } \\
\text { er } \\
(\mathrm{m})\end{array}$ & $\begin{array}{l}\text { Lengt } \\
\qquad \begin{array}{c}\mathrm{h} \\
(\mathrm{m})\end{array}\end{array}$ & $\begin{array}{c}\text { Volum } \\
\text { e } \\
(\mathrm{M} \\
\left.\mathrm{m}^{3}\right) \\
\end{array}$ & $\begin{array}{c}\text { Surface Area } \\
\left(\mathrm{m}^{2}\right)\end{array}$ & $\begin{array}{l}\text { Total } \\
\text { heig } \\
\text { ht } \\
(\mathrm{m})\end{array}$ \\
\hline 1 & $\begin{array}{c}\text { Junction } \\
\text { for } \\
\text { pipes } \\
\end{array}$ & 0 & 1 & 3.6 & 305 & 18 & 300,000 & 60 \\
\hline 2 & $\begin{array}{l}\text { Reservo } \\
\text { ir as } \\
\text { recharge } \\
\text { source } \\
\end{array}$ & $\begin{array}{c}60, \text { also the } \\
\text { maximum } \\
\text { recovery } \\
\text { level }\end{array}$ & 2 & 3 & 305 & & & \\
\hline 3 & $\begin{array}{c}\text { Junction } \\
\text { for } \\
\text { pipes } \\
\end{array}$ & 10 & 3 & 2.4 & 305 & & & \\
\hline 4 & $\begin{array}{c}\text { Junction } \\
\text { for } \\
\text { pipes }\end{array}$ & 15 & 4 & 1.8 & 305 & & & \\
\hline 5 & $\begin{array}{c}\text { Junction } \\
\text { for } \\
\text { pipes } \\
\end{array}$ & 30 & 5 & 3.6 & 305 & & & \\
\hline 6 & $\begin{array}{c}\text { Open } \\
\text { tank as } \\
\text { the } \\
\text { mine } \\
\text { void }\end{array}$ & 0 & & & & & & \\
\hline
\end{tabular}

The challenges of using the pipe-network model lies in the design of the network that represents the mine voids and groundwater pathways. This is the shortcoming for more sophisticated models that use network modeling for non-Darcian flows (Zhou et al. 2011). Due to the extensive data requirements on underground maps and groundwater level measurements, the pipe-network model is not applicable to larger areas because the required input parameters are often unavailable.

\subsection{Pipe-Pond Model}

Pipe-pond models are semi-distributed models in which flow within large volumes of mine voids are represented as 'ponds' (each characterized by a single water level across the entire pond) and the inter-pond connections are represented by pipe flow equations (Sherwood and Younger 1997; Banks 2001). This type of model is essentially a combination of the pipe-network model and the black-box model. The flow paths are described by the pipe-network, while the mine voids of large volumes are described by black-boxes. In applications of the pond-pipe model, the data requirement is not as extensive as the pipe-network and the results can be more meaningful than the black-box model. Examples of such models are GRAM model (Groundwater Rebound in Abandoned Mine workings) (Burke \& Younger 2000; Kim \& Choi 2018), mixing-cell model (Zhou 2000), and EPANET model (Rossman 2000). Several studies using the GRAM model have been carried out to analyze the mine groundwater rebound phenomenon associated with a coal field in South Yorkshire, UK (Gandy \& Younger 2007; Kortas \& Younger 2007). The GRAM model considers water in each pond to be completely mixed and the ponds to be interconnected with horizontal pipes.

The EPANET model was actually developed for the simulation of water distribution in piping systems. However, it has all the components of a pipe-pond model. This model has several advantages over the GRAM model including the following: accommodating all pipe flow equations as discussed in the pipe-network model; mixing mechanisms in ponds including complete mix, plug flow, or twocompartment mixing; predicting tracer movement and water age; and being available in the public domain.

An example of the application of the pipe-pond model is shown in Figure 5. The model consists of 12 nodes and 14 pipes. Of the 12 nodes, four represent recharge sources and four represent interconnected mine voids. The parameters of the nodes and pipes are presented in Table 5. Figure 6 shows the predicted groundwater level rebound, together with the predicted inflow rate to each of the 
Approaches of Applying Non-Darcian Flow Equations to Predicting Groundwater Rebound in Response to Coal Mine Closure

mine voids. Clearly, the inflow rate to each of the mine voids decreases with the groundwater rebound. At the end of simulation, the total inflow rate is less than $5 \mathrm{~L} / \mathrm{s}$, or $0.4 \mathrm{~L} / \mathrm{s}$ to $30 \mathrm{~m}$ mine void, $0.13 \mathrm{~L} / \mathrm{s}$ to $15 \mathrm{~m}$ mine void, $0.68 \mathrm{~L} / \mathrm{s}$ to $10 \mathrm{~m}$ mine void, and $3.5 \mathrm{~L} / \mathrm{s}$ to the $0 \mathrm{~m}$ mine void. The groundwater rebound appears to reach asymptotic condition after 2.5 years.

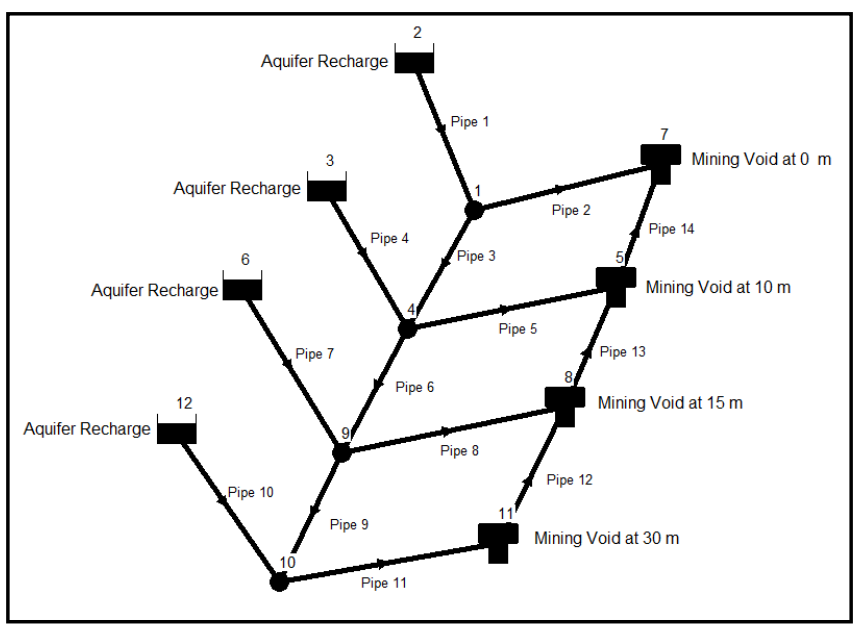

Figure5. Example pipe-pond model for groundwater rebound simulation

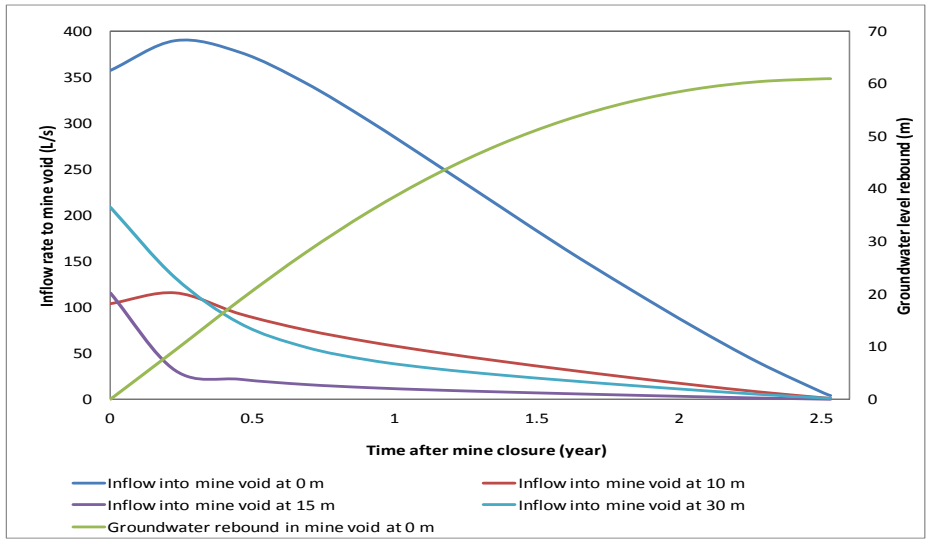

Figure6. Groundwater rebound prediction for pipe-pond mode in Figure 5 using pipe-pond model

Table5. Parameters for the pipe network shown in Figure 5

\begin{tabular}{|c|c|c|c|c|c|c|c|c|c|}
\hline \multicolumn{3}{|c|}{ Node } & \multicolumn{3}{|c|}{ Pipe } & \multicolumn{4}{|c|}{ Mine void } \\
\hline $\begin{array}{c}\text { Node } \\
\text { Number }\end{array}$ & Feature & $\begin{array}{l}\text { Elevation } \\
\text { (m) }\end{array}$ & $\begin{array}{c}\text { Pipe } \\
\text { Number }\end{array}$ & $\begin{array}{l}\text { Diameter } \\
\text { (m) }\end{array}$ & $\begin{array}{l}\text { Length } \\
\text { (m) }\end{array}$ & $\begin{array}{l}\text { Level } \\
(\mathrm{m})\end{array}$ & $\begin{array}{l}\text { Volume } \\
\left(\mathrm{M} \mathrm{m}^{3}\right)\end{array}$ & $\begin{array}{c}\text { Surface } \\
\text { Area } \\
\left(\mathrm{m}^{2}\right)\end{array}$ & $\begin{array}{l}\text { Height } \\
\text { (m) }\end{array}$ \\
\hline 1 & $\begin{array}{l}\text { Junction } \\
\text { for pipes }\end{array}$ & 0 & 1 & 3.7 & 305 & 0 & 60 & 300,000 & 200 \\
\hline 2 & $\begin{array}{l}\text { Reservoir } \\
\text { as } \\
\text { recharge } \\
\text { source }\end{array}$ & $\begin{array}{c}60, \\
\text { maximum } \\
\text { recovery } \\
\text { level }\end{array}$ & 2 & 3.0 & 305 & 10 & 15 & 73,000 & 200 \\
\hline 3 & $\begin{array}{l}\text { Reservoir } \\
\text { as } \\
\text { recharge } \\
\text { source }\end{array}$ & $\begin{array}{c}60, \\
\text { maximum } \\
\text { recovery } \\
\text { level }\end{array}$ & 3 & 3.7 & 305 & 15 & 4 & 20,000 & 200 \\
\hline 4 & $\begin{array}{l}\text { Junction } \\
\text { for pipes }\end{array}$ & 10 & 4 & 3.0 & 305 & 30 & 15 & 73,000 & 200 \\
\hline 5 & $\begin{array}{l}\text { Open tank } \\
\text { as mine } \\
\text { void }\end{array}$ & 10 & 5 & 2.4 & 305 & & & & \\
\hline 6 & $\begin{array}{c}\text { Reservoir } \\
\text { as } \\
\text { recharge }\end{array}$ & $\begin{array}{c}60, \\
\text { maximum } \\
\text { recovery }\end{array}$ & 6 & 3.0 & 305 & & & & \\
\hline
\end{tabular}


Approaches of Applying Non-Darcian Flow Equations to Predicting Groundwater Rebound in Response to Coal Mine Closure

\begin{tabular}{|c|c|c|c|c|c|c|}
\hline & source & level & & & & \\
\hline 7 & $\begin{array}{c}\text { Open tank } \\
\text { as mine } \\
\text { void }\end{array}$ & 0 & 7 & 1.2 & 305 & \\
\hline 8 & $\begin{array}{l}\text { Open tank } \\
\text { as mine } \\
\text { void }\end{array}$ & 15 & 8 & 1.8 & 305 & \\
\hline 9 & $\begin{array}{l}\text { Junction } \\
\text { for pipes }\end{array}$ & 15 & 9 & 3.7 & 305 & \\
\hline 10 & $\begin{array}{l}\text { Junction } \\
\text { for pipes }\end{array}$ & 30 & 10 & 3.7 & 305 & \\
\hline 11 & $\begin{array}{l}\text { Open tank } \\
\text { as mine } \\
\text { void }\end{array}$ & 30 & 11 & 3.7 & 305 & \\
\hline \multirow[t]{3}{*}{12} & $\begin{array}{l}\text { Reservoir } \\
\text { as } \\
\text { recharge } \\
\text { source }\end{array}$ & $\begin{array}{c}60, \\
\text { maximum } \\
\text { recovery } \\
\text { level }\end{array}$ & 12 & 3.7 & 305 & \\
\hline & & & 15 & 3.7 & 305 & \\
\hline & & & 14 & 3.7 & 305 & \\
\hline
\end{tabular}

\subsection{Predicting Water Quality in Mine Voids}

Prediction of post-closure water quality is very challenging (Younger 1997; 2000). The fate and transport of chemical constituents are certainly not amenable to precise, quantitative simulation. Any estimate must be presented in a manner that acknowledges the irreducible uncertainties. In broad terms, the chemical content of the mine water flowing into mine voids will reflect the chemical contents of the widely-worked coal seams and surrounding formations. Dissolution and oxidation may increase the chemical concentrations temporarily, similar to the first-flush phenomenon in water quality of storm water runoff. Accurate prediction of a wide range of parameters in response to mine closure is beyond present capabilities. However, the pipe-pond model can be a simplified prediction protocol for water quality trend evaluation.

The pipe-pond model shown in Figure 5 was used to demonstrate the screening level prediction of water quality change in mine voids during the rebound process. If recharge source \#2 is also a contamination source of a conservative chemical with a concentration $100 \mathrm{mg} / \mathrm{L}$, Figure 7 shows the concentration variations in the four mine voids under the assumption of complete mixing. The mine void at $0 \mathrm{~m}$ level is impacted the most, whereas the mine void at $30 \mathrm{~m}$ level is impacted the least. The concentration in the $0 \mathrm{~m}$ mine void decreases gradually after reaching the peak at approximately 73 $\mathrm{mg} / \mathrm{L}$. The concentration reaches the asymptotic level of $56 \mathrm{mg} / \mathrm{L}$ after 2.5 years. This is because approximately $56 \%$ of water flowing to the $0 \mathrm{~m}$ mine void comes from source recharge \#2. As expected, the chemical concentrations in the mine voids depend on the distance from the contamination source, the larger the distance, the lower the chemical concentration.

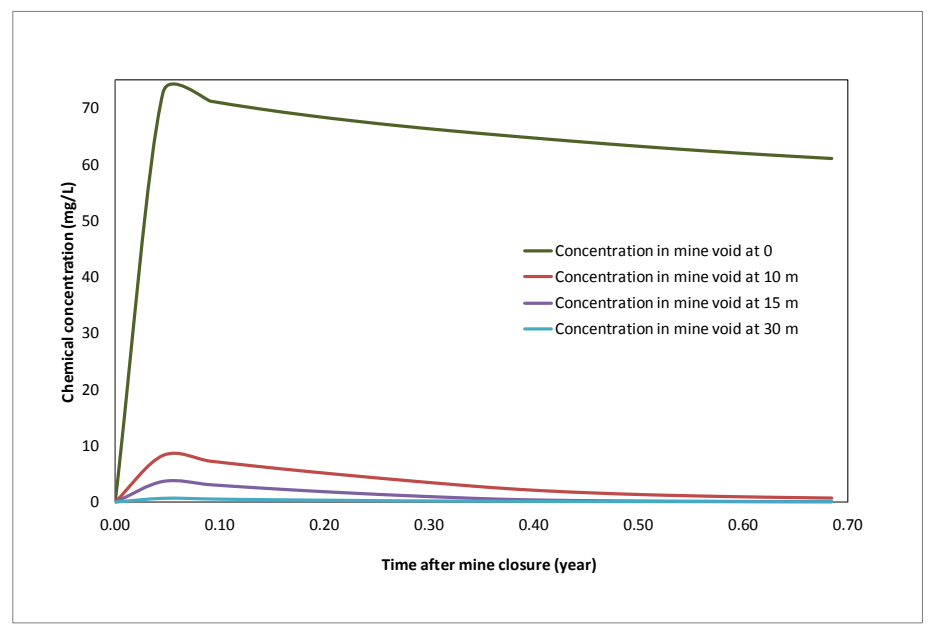

Figure7. Predicted chemical concentrations in mine voids for pipe-pond mode in Figure 5 using pipe-pond model 


\section{CONCLUSION}

Mathematical modeling of groundwater rebound in response to mine closure can be complicated. Mine workings consisting of mined out areas, shafts, and roadways represent preferential flow pathways with variable and difficult-to-estimate geometric and hydraulic properties. Groundwater flow in these large open mine voids is typically turbulent. Moreover, mining activities can induce additional fractures in surrounding formations, and back-filling practices can reduce the void volume. The closed mines are multi-porosity media. Traditional Darcian-flow based groundwater flow models do not provide the correct simulation of the multi-porosity media with preferential flow along mine voids for post-closure prediction. This paper introduces three types of models that account for nonDarcian flow in mine voids: black-box model, pipe-network model, and pipe-pond models. Depending on volume of mine voids and their connections, these models can predict the general trend in groundwater rebound and water quality. They can help determine the general timeframes to approach the full recovery. In particular, the black-box approach, which does not require detailed geometric and hydraulic data in mine voids, takes advantage of the routine mining records on mining plan and dewatering activity. The results from these rudimentary analyses help determine if and where the monitoring and remediation efforts should be made in response to the mine closure.

\section{REFERENCES}

[1] Adams R 2014. A Review of mine water rebound predictions from the VSS-NET Model. Mine Water and the Environment, 33: 384-388, DOI: 10.1007/s10230-014-0312-6.

[2] Adams R, Younger PL 1997. Simulation of groundwater rebound in abandoned mines using a physically based modeling approach. In: Veselic M, Norton PJ (editors) Proceedings of the 6th International Mine Water Association Congress, Mine water and the Environment, 2: 353-362.

[3] Adams R, Younger PL 2001. A strategy for modeling ground water rebound in abandoned deep mine systems. Ground Water, 39: 249-261.

[4] Aljoe WW 1994. Hydrologic and water quality characteristics of a partially-flooded, abandoned underground coal mine. Proceedings of the International Land Reclamation and Mine Drainage Conference and the Third International Conference on the Abatement of Acidic Drainage. Pittsburgh, PA, April 1994, Volume 2. US Bureau of Mines Special Publication SP 06B-94, 178-187.

[5] Banks D 2001. A variable-volume, head-dependent mine water filling model: Ground Water, 39(3): 362365.

[6] Burke SP, Younger PL 2000. Groundwater rebound in the South Yorkshire Coalfield: a first approximation using the GRAM Model. Quarterly Journal of Engineering Geology and Hydrogeology, 33: 149-160.

[7] Cui FP, Q Wu, YH Lin, YF Zeng, KL Zhang 2018. Damage features and formation mechanism of the strong water inrush disaster at the Daxing Coal Mine, Guangdong Province, China. Mine Water and the Environment, 37(2): 346-350.

[8] Dinger JS, Cumbie DH, Davidson B 2006. Assessing Water-Supply Potential of Abandoned Underground Coal Mines in Eastern Kentucky. Kentucky Geological Survey, Report of Investigations 12, pp36.

[9] Feng MS 2006.The Study on Groundwater Pollution in Abandon Cola Mine. Liaoning University of Engineering and Technology, 2(7): 11-19.

[10] Gandy CJ, Younger PL 2007, Predicting rebound in the South Yorkshire coalfield, U.K. Mine Water and the Environment, 26: 70-78.

[11] Gzyl G, Banks D 2007. Verification of the "first flush" phenomenon in mine water from coal mines in the Upper Silesian Coal Basin, Poland. Journal of Contaminant Hydrology, 92 (1-2): 66-86.

[12] Hamm V, Collon-Drouaillet P, Fabriol R 2008. Two modeling approaches to water-quality simulation in a flooded iron-ore mine (Saizerais, Lorraine, France): A semi-distributed chemical reactor model and a physically based distributed reactive transport pipe network model. Journal of Contaminant Hydrology, 96 (1-4): 97-112.

[13] Hobba, JRW 1987. Underground Coal Mines as Sources of Water for Public Supply in Northern Upshur County, West Virginia, U. S. Geological Survey Water-Resources Investigations Report 84-4115.

[14] Huisamen A, Wolkersdorfer C 2016. Modelling the hydrogeochemical evolution of mine water in a decommissioned opencast coal mine. Int. J. Coal Geol., 164: 3-12.

[15] Hu WY, Zhou JJ \& Yan LY 2010. Study on environment and safety disasters from abandoned coal mines, Journal of Xi'an University of Science and Technology, 30(4): 436-440. 
[16] Jardine CN, Boardman B, Osman A, Vowles J, Palmer J 2009. Coal mine methane. In: Jardine CN, Boardman B, Osman A, Vowles J, Palmer, J (editors), Methane UK. Environmental Change Institute, University of Oxford, 64-71.

[17] Kim SM, Choi Y 2018. SIMPL: A simplified model-based program for the analysis and visualization of groundwater rebound in abandoned mines to prevent contamination of water and soils by acid mine drainage. Int. J. Environ. Res. Public Health, 15, 951, doi 0.3390/ijerph15050951.

[18] Kortas L, Younger PL 2007. Using the GRAM model to reconstruct the important factors in historic groundwater rebound in part of the Durham coalfield, UK. Mine Water and the Environment, 26: 60-69.

[19] Ladwig KJ, Erickson PM, Kleinmann RLP, Posluszny ET 1984. Stratification in water quality in inundated anthracite mines, eastern Pennsylvania. U S Bureau of Mines Report of Investigations RI-8837. US Bureau of Mines, Pittsburgh, 35pp.

[20] Liu P, Sun YJ 2011. Discussion on groundwater pollution caused by abandoned mines and its controlling techniques, Mining R \& D, 31(4): 91-95.

[21] Li T 2014. Study on Groundwater Pollution Risk Assessment of Abandoned Coal Mine. China University of Mining and Technology Publishing House.

[22] Light DDM \& Donovan JJ 2015. Mine-water flow between contiguous underground coal mines with hydraulically compromised barriers. Environmental \& Engineering Geoscience, 21(2): 147-164.

[23] Love E, Hammack R, Harbert W, Sams J, Veloski G, Ackman T 2005. Using airborne thermalinfrared imagery and helicopter EM conductivity to locate mine pools and discharges in the Kettle Creek Watershed, North-Central Pennsylvania. Geophysics, 70(6): B73-B81.

[24] McCoy KJ, Donovan JJ, Leavitt BR 2006. Horizontal hydraulic conductivity estimates for intact coal barriers between closed underground mines. Environmental \& Engineering Geosciences, 12(3): 273-282.

[25] Ordoñez A, Jardon S, Álvarez R, Andrés C, Pendas F 2012. Hydrogeological definition and applicability of abandoned coal mines as water reservoirs. Journal of Environmental Monitoring, 14(8): 2127-2136, doi: 10.1039/c2em11036a.

[26] PA Department of Environmental Protection 2003. Quecreek Mine Inundation, Report of Investigation. Commonwealth of Pennsylvania, Department of Environmental Protection, Bureau of Deep Mine Safety, July.

[27] Pan Y, Liu Y, Zeng XK, Wu JC 2017. Numerical simulation of groundwater flow field evolution in abandoned mine in the east Xuzhou, Hydrogeology \& Engineering Geology, 44:52-56.

[28] Pan ZY, Jiang XZ, Lei MT, Guan ZD, Wu YB, Gao YL 2018. Mechanism of sinkhole formation during groundwater-level recovery in karst mining area, Dachengqiao, Hunan province, China, Environmental Earth Sciences, 77:799, doi 10.1007/s12665-018-7987-0

[29] Shoemaker WB, Kuniansky EL, Birk S, Bauer S, Swain ED 2008. Documentation of a Conduit Flow Process (CFP) for MODFLOW-2005, Techniques and Methods, Book 6, Chapter A24, U.S. Geological Survey.

[30] Sherwood JM, Younger PL 1997. Modelling groundwater rebound after coalfield closure. In: Chilton, P.J., et al, (editors), Groundwater in the urban environment, Volume 1: Problems, processes and management. A.A. Balkema Publishers, Rotterdam. 165 - 170.

[31] Stoertz MW, Hughes ML, Wanner NS, Farley ME 2001. Long-term water quality trends at a sealed, partially flooded underground mine. Environmental \& Engineering Geosciences, 12(1):51-65.

[32] Toran L, Bradbury KR 1988. Groundwater flow model of drawdown and recovery near an underground mine. Ground Water, 26: 724-733.

[33] U. S. Environmental Protection Agency 2017. Planning for Response Actions at Abandoned Mines with Underground Workings: Best Practices for Preventing Sudden, Uncontrolled Fluid Mining Waste Releases. OLEM 9200.3-118, July.

[34] U. S. Office of Surface Mining 2014. Final Report Fairmont, West Virginia Mine-pool, prepared by Technical Support Division, Pittsburgh, PA for West Virginia Department of Environmental Protection, Division of Mining and Reclamation, Charleston, WV, March.

[35] Winters RW, Capo RC 2004. Ground water flow parameterization of an Appalachian coal mine complex. Ground Water, 42(5): 700-710.

[36] Wood SC, Younger PL, Robins NS 1999. Long-term changes in the quality of polluted minewater discharges from abandoned underground coal workings in Scotland. Quarterly Journal of Engineering Geology, 32: 69-79.

[37] Wolkersdorfer C 2006. Water Management at Abandoned Flooded Underground Mines. Springer

[38] Wolkersdorfer C, Hasche A 2003. Tracer investigations in flooded mines - the strassberg/harz multitracer test, Proceedings of Groundwater Management in Mining Areas. Pécs, Hungary, June 23-27. 
[39] Younger PL 1997. The longevity of minewater pollution: a basis for decision-making. Science of the Total Environment, 194/195: 457-466.

[40] Younger PL 2000. Predicting temporal changes in total iron concentrations in groundwaters flowing from abandoned deep mines: a first approximation. Journal of Contaminant Hydrology, 44: 47-69.

[41] Younger PL 2014. Hydrogeological challenges in a low-carbon economy. Quarterly Journal of Engineering Geology and Hydrogeology, 47(1): 7-27, doi 10.1144/qjegh2013-063.

[42] Younger PL 2016. A simple, low-cost approach to predicting the hydrogeological consequences of coalfield closure as a basis for best practice in long-term management. International Journal of Coal Geology, 164: 25-34, doi 10.1016/j.coal.2016.06.002.

[43] Younger PL, Thorn P 2006. Predictions and reality: generation of strongly net-acidic mine waters through flooding of underground coal mine workings with limestone roof strata, Blenkinsopp colliery (Northumberland, UK). Proceedings of the 7th International conference on Acid Rock Drainage, St Louis, MO, 2542-2557.

[44] Younger PL, Banwart SA, Hedin, RS, 2002, Mine Water: hydrology, pollution, remediation. Kluwer Academic Publishers, Dordrecht. 464pp.

[45] Wu Q, Shen JJ, Wang Y 2017. Mining techniques and engineering application for "coal-water" dualresources mine, Journal of China Coal Society, 42(1):8-16.

[46] Zeng YF, Zhou W, LaMoreaux J, 2017. Single-well circulation systems for geothermal energy transfer, Environ Earth Sci, 76:296, doi 10.1007/s12665-017-6621-X

[47] Zhou JJ, Hu WY, Zhang ZL 2006. Analysis on rule of groundwater movement and model establishment of current numerical simulation in abandon mines, Journal of China Coal Society, 31:70-73.

[48] Zhou JJ, Hu WY, Hou DY 2011. Numerical simulation of groundwater rebound process and water table value in abandoned mines, Coal Geology \& Exploration, 39(4): 28-31.

[49] Zhou W 2000. Studies of confluent flow in mature karst aquifers using analog models and numerical mixing cell models. In Sasowsky ID, Wicks CM (editors.): Groundwater Flow and Contaminant Transport in Carbonate Aquifers. A.A. Balkema, Rotterdam, 157-168.

Citation: Shuning Dong, et.al, (2020)" Approaches of Applying Non-Darcian Flow Equations to Predicting Groundwater Rebound in Response to Coal Mine Closure ", Southeast Cameroon, International Journal of Mining Science (IJMS), 6(1), pp.1-12, DOI: http://dx.doi.org/10.20431/2454-9460.0601001

Copyright: (C) 2020 Authors. This is an open-access article distributed under the terms of the Creative Commons Attribution License, which permits unrestricted use, distribution, and reproduction in any medium, provided the original author and source are credited 